\title{
Genetic Analysis of Kharif Onion Genotypes and their Performance Study in Plains of West Bengal
}

\author{
Swamini Bhoi ${ }^{1 *}$, Nishant Barik ${ }^{2}$, Tarique Aslam ${ }^{1}$, \\ Sankhendu Bikash Chattopadhyay ${ }^{1}$ and Tapan Kumar Maity ${ }^{1}$ \\ ${ }^{1}$ Department of Vegetable Science, Bidhan Chandra Krishi Viswavidyalaya, \\ Mohanpur, Nadia, West Bengal, 741252, India \\ ${ }^{2}$ Department of Horticulture, Assam Agricultural University, Jorhat, Assam, 785013, India
}

*Corresponding author

\section{A B S T R A C T}

\begin{tabular}{|l|}
\hline K e y w o r d s \\
$\begin{array}{l}\text { Kharif onion, } \\
\text { Genetic diversity, } \\
\text { Heritability }\end{array}$ \\
\hline Article Info \\
\hline $\begin{array}{l}\text { Accepted: } \\
\text { 17 August } 2020 \\
\text { Available Online: } \\
\text { 10 September } 2020\end{array}$ \\
\hline
\end{tabular}

Identification of ideal genotype is the utmost important to trigger desirable qualitative and quantitative characters. The present investigation was meant to assess the degree of variability, heritability, genetic advance and genetic divergence in kharif onion (Allium cepa L.) cultivars using eleven quantitative and six biochemical traits. Out of twenty-two cultivars Agrifound Dark Red had maximum yield whereas minimum recorded in Arka Bindu. The analysis of variance was highly significant for all the characters studied. Phenotypic coefficient of variance (PCV) was higher than genotypic coefficient of variance $(\mathrm{GCV})$ for all the traits but the difference was less in average bulb weight, TSS, total sugar, ascorbic acid, pyruvic acid and phenol. Such difference indicates higher contribution of genotypic effect towards phenotypic expression. High heritability along with high genetic advance as percent of mean was recorded in neck thickness, average bulb weight, total sugar, ascorbic acid, phenol and pyruvic acid which refers the presence of additive gene action for the expression of these traits. This study would ease the selection of potential genotypes for yield related traits and help breeders in selection of promising diverse parents for purposeful breeding programmes.

\section{Introduction}

India is the second largest onion (Allium cepa L.) producing country in the world with an output of 23.61 MT from an area of 1.2 MHa (NHB, 2019). More than 50\% of the vegetables export from India comprises of onion. Onion is produced in three seasons in our country i.e., Rabi, Kharif and late Kharif. Near about $60 \%$ production comes from Rabi crop while Kharif and late Kharif crops contribute 20 percent each. The significance of Kharif onion in checking the sky rocketing price during October-March and problem of bolting cum rotting in storage are well understood. Kharif onion has a major role in enhancing the area and production of the country. With the availability of suitable climate, Kharif onion cultivation is a recent introduction in North, Eastern and Central 
India. In West Bengal, onion is generally grown during Rabi season and the bulb is made available from April onwards only. Thus, dependence on other states (producing Kharif and late Kharif onion) for supply of bulbs during October to March leads to abnormally high price. This situation may be improved to some extent if the possibilities and potentialities of growing Kharif onion are being exploited. For initiation of an effective breeding programme for hybrid development, knowledge of genetic diversity is of prime importance. Genetic variation forms the base of plant breeding and provides an array of genotypes that can be selected to develop new varieties or breeding materials.

\section{Materials and Methods}

The experiment was carried out with twentytwo Kharif onion cultivars during Kharif season at C-block farm, BCKV, Kalyani, Nadia, West Bengal during 2016-17.

The soil in the research station is sandy loam in texture, fine, mixed with good water holding capacity. The physio-chemical properties and fertility status of the experimental soil are presented in the Table 1 .

The experiment was laid in Randomized Block Design (RBD) with three replications. Observations regarding growth parameters were taken from randomly selected ten plants per replication at 90 days after transplanting. In similar manner bulb characters and yield were recorded after harvest. Replication wise mean values of each of the 22 genotypes were computed for respective characters and subjected to statistical analysis. All the statistical analysis was carried out following OPSTAT (www.hau.ernet.in) statistical analysis tool. The GCV and PCV were worked out as per the method of Burton (1952) and heritability and genetic advance by following the method suggested by Lush (1949), Robinson et al., (1949) and Burton and De Vane (1953).

\section{Results and Discussion}

The analysis of variance was highly significant for all the characters. Highest yield was recorded in Agrifound Dark Red (249.33 q/ha) followed by BSS-258 (240.10 q/ha). Similarly, highest average bulb weight found in the variety Agrifound Dark Red (72.00 g) followed by BSS-258(68.00 g) (Table 2).

The extent of variability with respect to various characters in different genotypes was measured in terms of range, general mean, genotypic coefficient of variation (GCV), phenotypic coefficient of variation (PCV), heritability $\left(\mathrm{h}^{2}\right)$ and expected genetic advance as per cent of mean (Table 3 ).

Table.1 Physico-chemical properties of soil of the experimental field

\begin{tabular}{|l|l|l|}
\hline Particulars & Status & Amount \\
\hline Chemical composition & \multicolumn{2}{|l|}{} \\
\hline pH & Neutral & 7.2 \\
\hline EC & Normal & $0.22 \mathrm{dSm}-1$ \\
\hline Organic carbon & Low & $0.52(\%)$ \\
\hline Nitrogen & Low & $206.43 \mathrm{~kg} \mathrm{ha}-1$ \\
\hline Phosphorous & Low & $07.77 \mathrm{~kg} \mathrm{ha}-1$ \\
\hline Potassium & Medium & $185.46 \mathrm{~kg}$ ha-1 \\
\hline
\end{tabular}


Table.2 Physico-chemical parameters of different varieties

\begin{tabular}{|c|c|c|c|c|c|c|c|c|c|c|c|c|c|c|c|c|c|}
\hline & $\begin{array}{l}\text { Plant } \\
\text { height } \\
\text { (cm) }\end{array}$ & $\begin{array}{l}\text { No of } \\
\text { leaves }\end{array}$ & $\begin{array}{l}\text { Neck } \\
\text { Thick } \\
\text { ness } \\
(\mathbf{m m})\end{array}$ & $\begin{array}{l}\text { Polar } \\
\text { Diameter } \\
(\mathbf{m m})\end{array}$ & $\begin{array}{l}\text { Equatorial } \\
\text { diameter } \\
(\mathbf{m m})\end{array}$ & $\begin{array}{l}\text { Double } \\
(\%)\end{array}$ & $\begin{array}{l}\text { Bolting } \\
(\%)\end{array}$ & $\begin{array}{l}\text { Average } \\
\text { Bulb } \\
\text { Weight } \\
\text { (gm) }\end{array}$ & $\begin{array}{l}\text { Days to } \\
\text { Maturity }\end{array}$ & TSS & $\begin{array}{l}\text { Total } \\
\text { Sugar }\end{array}$ & $\begin{array}{l}\text { Dry } \\
\text { Matter }\end{array}$ & $\begin{array}{l}\text { Vitamin } \\
\text { C }\end{array}$ & $\begin{array}{l}\text { Pyruvic } \\
\text { Acid }\end{array}$ & Phenol & $\begin{array}{l}\text { Marketable } \\
\text { Yield }\end{array}$ & $\begin{array}{l}\text { Total } \\
\text { Yield }\end{array}$ \\
\hline Bhima Super & 61.00 & 9.00 & 9.80 & 41.47 & 46.95 & 1.03 & 5.66 & 56.35 & 128.00 & 16.80 & 2.68 & 11.96 & 7.32 & 3.17 & 2.80 & 189.96 & 200.70 \\
\hline $\begin{array}{l}\text { Agrifound } \\
\text { Dark Red }\end{array}$ & 65.00 & 9.66 & 5.80 & 47.60 & 52.13 & 0.73 & 8.00 & 72.00 & 130.00 & 14.70 & 1.54 & 12.33 & 5.34 & 2.16 & 6.23 & 242.26 & 249.33 \\
\hline Kohinoor-9 & 53.00 & 9.00 & 7.16 & 44.92 & 46.72 & 5.50 & 5.67 & 61.79 & 128.67 & 15.10 & 1.74 & 14.27 & 7.10 & 4.63 & 4.46 & 208.10 & 218.30 \\
\hline Indam Gulab & 50.33 & 7.33 & 6.36 & 44.88 & 49.74 & 1.00 & 7.00 & 49.64 & 135.33 & 14.47 & 2.13 & 12.44 & 6.05 & 1.27 & 4.90 & 166.83 & 179.33 \\
\hline Arka Bindu & 42.67 & 6.66 & 3.93 & 33.25 & 34.49 & 3.23 & 5.33 & 23.56 & 122.67 & 13.20 & 1.58 & 10.32 & 5.17 & 4.48 & 7.13 & 82.23 & 93.53 \\
\hline Arka Kalyan & 55.33 & 9.33 & 6.30 & 42.57 & 43.74 & 4.23 & 4.33 & 38.76 & 131.33 & 17.47 & 2.06 & 14.32 & 9.28 & 1.21 & 5.93 & 131.20 & 149.93 \\
\hline $\begin{array}{l}\text { Bhima } \\
\text { Shubhra }\end{array}$ & 54.33 & 7.67 & 7.67 & 44.55 & 50.33 & 1.73 & 5.33 & 57.95 & 132.00 & 15.43 & 2.48 & 12.47 & 10.18 & 3.31 & 3.17 & 199.00 & 205.53 \\
\hline $\begin{array}{l}\text { Arka } \\
\text { Kirtiman }\end{array}$ & 60.00 & 8.67 & 6.80 & 49.53 & 42.04 & 5.36 & 6.00 & 40.33 & 132.00 & 17.30 & 1.43 & 14.71 & 4.63 & 2.40 & 6.74 & 136.16 & 154.20 \\
\hline Arka Pragati & 58.00 & 10.00 & 7.10 & 46.77 & 50.92 & 6.53 & 8.33 & 57.29 & 133.33 & 16.06 & 2.51 & 12.12 & 7.19 & 1.07 & 4.25 & 193.16 & 211.26 \\
\hline Arka Lalima & 54.00 & 9.00 & 6.64 & 51.48 & 45.50 & 2.83 & 6.67 & 43.34 & 134.00 & 17.47 & 3.15 & 13.50 & 5.13 & 0.88 & 4.27 & 147.76 & 166.86 \\
\hline Bss 258 & 53.00 & 9.00 & 5.19 & 50.26 & 52.19 & 2.13 & 6.00 & 68.00 & 133.33 & 15.37 & 2.06 & 12.99 & 7.09 & 1.06 & 4.22 & 231.20 & 240.10 \\
\hline Bhima Sweta & 57.33 & 8.67 & 7.55 & 47.30 & 48.22 & 0.96 & 5.33 & 65.62 & 132.67 & 17.80 & 1.48 & 11.89 & 8.97 & 2.21 & 2.61 & 222.63 & 231.10 \\
\hline Bhima Red & 55.00 & 9.33 & 7.80 & 46.66 & 44.98 & 0.53 & 4.00 & 41.03 & 133.33 & 14.73 & 2.56 & 13.86 & 4.12 & 0.78 & 6.07 & 139.20 & 149.30 \\
\hline Bhima Raj & 60.67 & 9.67 & 8.77 & 49.11 & 43.99 & 2.33 & 8.00 & 66.41 & 132.00 & 15.43 & 2.76 & 13.78 & 4.71 & 1.25 & 4.21 & 224.63 & 233.73 \\
\hline $\begin{array}{l}\text { Bhima Dark } \\
\text { Red }\end{array}$ & 57.67 & 7.67 & 7.36 & 46.95 & 42.26 & 0.46 & 5.50 & 39.13 & 129.33 & 15.33 & 2.24 & 12.67 & 6.43 & 3.31 & 7.71 & 132.13 & 139.56 \\
\hline Lucifer & 61.66 & 11.00 & 11.46 & 48.20 & 46.19 & 1.66 & 7.80 & 47.27 & 134.00 & 16.43 & 2.48 & 11.24 & 10.96 & 0.94 & 5.00 & 160.53 & 168.96 \\
\hline Yellow Grano & 53.00 & 9.00 & 6.20 & 55.66 & 44.02 & 1.60 & 0.36 & 64.66 & 133.33 & 12.70 & 1.27 & 16.05 & 6.24 & 1.09 & 2.98 & 218.33 & 234.33 \\
\hline Baswant 780 & 50.33 & 7.67 & 8.31 & 46.21 & 46.50 & 4.00 & 6.33 & 65.41 & 132.67 & 13.53 & 1.70 & 11.38 & 5.23 & 5.48 & 4.52 & 223.67 & 234.76 \\
\hline $\begin{array}{l}\text { Indam } \\
\text { Hybrid-4 }\end{array}$ & 48.67 & 7.33 & 7.56 & 43.30 & 48.88 & 3.66 & 7.33 & 41.07 & 134.67 & 14.67 & 1.21 & 10.84 & 10.08 & 1.08 & 3.65 & 139.67 & 155.76 \\
\hline Arka Niketan & 53.00 & 7.33 & 8.10 & 44.06 & 46.66 & 3.50 & 4.33 & 49.07 & 136.33 & 15.20 & 2.51 & 11.11 & 6.24 & 0.95 & 7.41 & 165.00 & 184.00 \\
\hline Arka Bheem & 47.33 & 7.67 & 7.40 & 41.28 & 41.07 & 0.33 & 6.33 & 49.69 & 134.67 & 15.53 & 1.62 & 11.12 & 8.88 & 0.95 & 4.46 & 169.33 & 188.33 \\
\hline $\begin{array}{l}\text { Indam } \\
\text { Marshall }\end{array}$ & 50.33 & 7.33 & 8.76 & 46.26 & 53.56 & 1.00 & 3.67 & 59.44 & 137.33 & 15.17 & 1.72 & 13.59 & 5.40 & 2.60 & 9.40 & 200.33 & 213.43 \\
\hline CD & 5.39 & 1.43 & 0.89 & 5.80 & 5.56 & 2.77 & 2.07 & 4.18 & 5.34 & 1.02 & 0.24 & 1.64 & 0.60 & 0.40 & 0.33 & 3.08 & 3.49 \\
\hline $\mathrm{SE}(\mathrm{m}) \pm$ & $1.89 \mathrm{~s}$ & 0.50 & 0.31 & 2.03 & 1.95 & 0.97 & 0.72 & 1.46 & $1.87 \mathrm{~s}$ & 0.36 & 0.08 & 0.57 & 0.21 & 0.14 & 0.11 & 1.08 & 1.22 \\
\hline
\end{tabular}


Table.3 Genetic components of different Horticultural traits in onion

\begin{tabular}{|c|c|c|c|c|c|c|}
\hline Characters & Mean & Range & $\operatorname{GCV}(\%)$ & PCV (\%) & $\mathbf{h}^{2}$ & GA(\%) Mean \\
\hline Plant height(cm) & 54.62 & $42.66-65.00$ & 9.34 & 11.10 & 70.68 & 15.23 \\
\hline Number of leaves & 8.53 & $6.67-11.00$ & 10.84 & 14.86 & 53.17 & 17.22 \\
\hline Neck thickness(mm) & 7.36 & $3.93-11.46$ & 23.80 & 25.01 & 90.52 & 40.62 \\
\hline Polar diameter(mm) & 46.01 & $33.25-55.67$ & 8.24 & 11.19 & 54.19 & 12.28 \\
\hline Equatorial diameter(mm) & 46.41 & $34.49-53.56$ & 8.20 & 10.95 & 56.06 & 12.50 \\
\hline Doubling & 2.46 & $0.33-6.53$ & 47.94 & 74.63 & 41.26 & 69.88 \\
\hline Bolting & 5.79 & $0.367-8.33$ & 21.61 & 24.84 & 75.70 & 34.88 \\
\hline Average bulb weight(g) & 52.62 & $23.56-72.00$ & 25.17 & 25.66 & 96.24 & 47.28 \\
\hline A Grade & 40.43 & $25.66-55.33$ & 21.22 & 22.49 & 89.05 & 43.00 \\
\hline Days to maturity & 132.31 & $122.66-135.3$ & 8.07 & 11.85 & 46.37 & 21.96 \\
\hline Total soluble solids $\left({ }^{\circ}\right.$ brix $)$ & 15.45 & $12.7-17.8$ & 8.90 & 9.79 & 82.59 & 15.79 \\
\hline Total sugar(mg/g) & 2.04 & $1.43-3.15$ & 24.49 & 25.52 & 92.12 & 52.34 \\
\hline $\operatorname{Dry}$ matter(g/100g) & 12.68 & $9.77-16.05$ & 11.04 & 13.62 & 65.76 & 16.81 \\
\hline Vit-C & 6.90 & $4.12-10.96$ & 27.34 & 27.83 & 96.55 & 58.67 \\
\hline Pyruvic acid( $\mu$ mole/g) & 2.10 & $0.78-5.48$ & 61.6 & 62.69 & 95.81 & 44.80 \\
\hline Phenol(mg/g) & 5.09 & $2.98-9.40$ & 34.00 & 34.25 & 98.54 & 71.22 \\
\hline Marketable yield(q/ha) & 178.33 & $82.23-242.26$ & 22.74 & 22.76 & 99.79 & 48.31 \\
\hline Total yield(q/ha) & 195.29 & $93.53-249.33$ & 20.33 & 20.36 & 99.71 & 43.59 \\
\hline
\end{tabular}

Phenotypic coefficient of variance (PCV)

The PCV was found to be greater than GCV for all the characters as reported by Chattopadhyay et al., (2013). The highest PCV was recorded in double bulb (74.63\%) followed by pyruvic acid (62.69\%), phenol (34.25\%), vitamin C (27.83\%), average bulb weight $(25.66 \%)$, neck thickness $(25.01 \%)$, total sugar $(25.52 \%)$, bolters $(24.84 \%)$, marketable yield $(22.76 \%)$ and total yield (20.36\%). However, moderate to high PCV was found for most of the characters except TSS $(9.79 \%)$. While moderate amount of PCV was recorded in equatorial diameter $(10.95 \%)$, plant height $(11.10 \%)$, polar diameter (11.19\%), days to maturity $(11.85 \%)$, dry matter $(13.62 \%)$ and number of leaves $(14.86 \%)$.

\section{Genotypic coefficient of variance (GCV)}

The GCV ranged from $8.07 \%$ (days to maturity) to $61.6 \%$ (pyruvic acid). High GCV was recorded in pyruvic acid (61.68\%) followed by double bulb (47.94\%), phenol (34.00\%), vitamin C content (27.34\%), average bulb weight $(25.17 \%)$, total sugar (24.49\%), neck thickness $(23.80 \%)$ and marketable yield $(22.74 \%)$. Moderate amount of GCV was estimated in number of leaves $(10.84 \%)$ and dry matter $(14.00 \%)$. Low estimates of GCV were observed in days to maturity $(8.07 \%)$ followed by equatorial diameter (8.20\%), polar diameter (8.24\%), TSS (8.90\%) and plant height (9.34\%).

The narrow difference between GCV and PCV were observed in total yield, marketable yield, phenol, pyruvic acid and vitamin $\mathrm{C}$ content. This indicates the less influence of environment and that the character expressions are totally due to genetic makeup. But wide difference between GCV and PCV observed in double bulb, number of leaves and polar diameter signified that there was large influence of growing environment.

Most of the traits viz, plant height, neck thickness, average marketable bulb weight, 
bolters, total yield, marketable yield, total soluble solids, total sugar, dry matter, vitamin $\mathrm{C}$, pyruvic acid and phenol content in bulbs showed high heritability $(65.76 \%-99.79 \%)$ coupled with moderate $(12.28 \%-17.22 \%)$ to high amount of genetic advance $(34.88 \%$ $71.22 \%$ ) except days to maturity $(2.96 \%)$. As these characters showed least influence by environment effect and accompanied by high heritability coupled with genetic advance, the additive gene effect might be the influencing factor for inheritance pattern of such traits. These findings were in accordance with Santra et al., (2017) and Chavan and Jayappa (2019)

From the undertaken research it would be concluded that among twenty two different onion varieties tested for their performance under plains of West Bengal, the varieties., Agrifound Dark Red, BSS-258, Baswant 780, Yellow Grano, Bhima Raj and Bhima Sweta were found better performers with respect to their yield potential, with good quality parameters compared to other varieties which could be used as source for further crop improvement programme and ultimately to increase yield and productivity.

\section{References}

Burton, G. W. 1952. Quantitative inheritance in grasses. In: Proceedings of 6th International Grassland Congress. 1: 277-288
Burton, G. W. and Devane, E. H. 1953. Estimating heritability in tall fescue (Festuca arundiancea) from replicated clonal material. Agronomy Journal. 45: 478-81.

Chavan, S. S., and Jayappa, J. 2019. Genetic variability and correlation studies in onion (Allium cepa L.) genotypes. Journal of Pharmacognosy and Phytochemistry, 8(6), 2242-2247.

Chattopadhyay, A., Sharangi, A. B., Dutta, S., Das, S. and Denre, M. 2013. Genetic relatedness between quantitative and qualitative parameters in onion (Allium cepa $\mathrm{L})$. Vegetos 26(1): 151-157.

Gurjar, R. S. S. and Singhania, D. L. 2006. Genetic variability, correlation and path analysis of yield and yield components in onion. Indian Journal of Horticulture. 63(1): 53-58.

Lush, J. L. 1949. Heritability and quantitative characters in farm animals. In: Proceedings of the 6th International Congress Genetics. Pp.356.

Robinson, H. F., Comstock, R. E. and Harvey, P. H. 1949. Estimates of heritability and the degree of dominance in corn. Agronomy Journal. 41: 353-359.

Santra, P., Manna, D., Sarkar, H. K., and Maity, T. K. 2017. Genetic variability, heritability and genetic advance in kharif onion (Allium cepa L.). Journal of Crop and Weed, 13(1), 103-6.

\section{How to cite this article:}

Swamini Bhoi, Nishant Barik, Tarique Aslam, Sankhendu Bikash Chattopadhyay and Tapan Kumar Maity. 2020. Genetic Analysis of Kharif Onion Genotypes and their Performance Study in Plains of West Bengal. Int.J.Curr.Microbiol.App.Sci. 9(09): 2323-2327.

doi: https://doi.org/10.20546/ijcmas.2020.909.290 